\title{
Antioxidant System Response of Freshwater Mussel Anodontacygnea to Cadmium Exposure
}

\author{
Irina V. Sukhovskaya ${ }^{1}$, Ekaterina V. Borvinskaya ${ }^{1}$, Albina A. Kochneva ${ }^{1}$, Zakhar \\ I. Slukovsky ${ }^{2,4}$, Stanislav R. Kurpe ${ }^{3}$, and Natalia N. Fokina ${ }^{1}$ \\ ${ }^{1}$ Institute of Biology of Karelian Research Centre of Russian Academy of Sciences, Petrozavodsk, \\ Russia \\ ${ }^{2}$ Institute of Geology of the Karelian Research Centre of RAS, Petrozavodsk, Russia \\ ${ }^{3}$ Petrozavodsk State University, Petrozavodsk, Russia \\ ${ }^{4}$ Institute of the North industrial ecology problems of Kola Science Center of RAS, Apatity, Russia
}

\section{Abstract}

Cadmium is one of widespread toxic substances being hazardous for man as it capable to enter from the environment into animal and plant tissues and spreading along the food chain. We have studied the effect of $\mathrm{Cd}$ on the gills and hepatopancreas of the fresh water bivalve mollusks Anodontacygnea. After12-day acclimation the mollusks were kept for 24 and 72 hours in aquariums with $\mathrm{Cd} 2+$ concentrations of 10,50 and 100 $\mu \mathrm{g} / \mathrm{L}$. Mass-spectrometric analysis has shown that $\mathrm{Cd}$ accumulation rate increased with increasing metal concentration in the water. At cadmium concentration of $100 \mu \mathrm{g} / \mathrm{L}$ the mollusk was capable of accumulating up to $0.44 \mu \mathrm{g}$ of $\mathrm{Cd}$ per day. The accumulation of such high metal concentrations in the mollusk tissues did not kill the animals, but signs of oxidative stress, more pronounced in the gills than in the digestive gland, were observed. Exposure to cadmium ions decreased GSH concentration and increase Px activity in the mollusk gills as early as 24 hours after the beginning of the experiment. Changing the water in the aquarium had a considerable influence on SOD activity in the gills comparable with the effect of the addition of $\mathrm{Cd}$.

\section{Keywords: cadmium, antioxidant defense, cadmium bioaccumulation}

\section{Introduction}

Cadmium (Cd) is one of common pollutants that are toxic for aquatic organism even at low $(0.5$-- $5.0 \mu \mathrm{g} / \mathrm{L})$ concentrations [1, 2]. The pollutant is supplied in to the environment upon anthropogenic activity, especially mineral extraction, burning of fuel and the production and disposal of accumulators [3]. This metal is the eighth in a list of 20 priority hazardous substances [4] whose concentrations have increased substantially during industrialization in rivers, estuaries, littoral zones, etc. [5].

The toxic effect mechanism of cadmium is still not fully understood. Unlike many S OPEN ACCESS heavy metals, cadmium ions do not trigger the generation of free radicals. However, 
cadmium poisoning is associated with the progression of oxidation processes, i.e "oxidative stress" [6]. Oxidative stress is provoked by the disbalance of reactive oxygen species (ROS) and is accompanied by peroxide oxidation of lipids, damage of proteins and DNA [7]. Living organisms have various biochemical systems of defense for the deactivation and removal of AOS. The anti-oxidative system (AOS) comprises lowmolecular compounds such as glutathione, vitamins $A$ and $E$ and anti-oxidative enzymes, e.g. superoxide dismutase (SOD), catalase (CAT), peroxidase $(P x)$ and glutathione Stransferase (GST) [8]. These biochemical parameters can be used to assess the resistance of an organism to oxidative stress provoked by heavy metal accumulation [9].

Cadmium exerts toxic effect presumably because it replaces major cations ( $\mathrm{Zn} 2+$, $\mathrm{Mn2}+, \mathrm{Cu} 2+$, etc.) in competitive manner in the active centers of anti-oxidative enzymes or directly bound to sulfhydryl groups of protein [6]. This lead to disturbing of AOS functioning, depletion of low-molecular reducers reserves (glutathione, etc.), and eventually the oxidation-reduction imbalance and cells apoptosis [3]; at the organism level acceleration of ageing, decreasing of the resistance to diseases and declining of reproductive ability occurs [10].

Ability of cadmium to be taken from the environment and accumulated by animal and plant tissues is characteristic that determines its toxicity. Of special concern are sedentary mollusks, because they are cannot actively avoid the pollutants [11]. Bivalve mollusks are most sensitive to toxic influence, because they filter off tremendous amounts of water and, together with suspended particles, consume heavy metal ions. It has been shown that sea mollusks, e.g. oysters, can absorb Cd up 104 times of those in sea water and, therefore, are widely used bioindicators of cadmium pollution in a near-shore environment [12].

As mollusk can accumulate phenomenal metal concentrations, study of their molecular mechanism of adaptation to this type of pollution is needed [13]. It should be noted that although there are many studies of marine bivalves under trace metal exposure, the literature on freshwater mollusks is scanty. The goal of the present work was to study possible relationships between cadmium concentration in the water and AOS enzyme activity in swan mussel Anodontacygnea, a freshwater bivalve mollusk upon the single and multiple introduction of cadmium into the medium. Cadmium accumulation in the mollusk tissues, depending on the duration of the exposure and water metal concentration, was also studied. As Anodonta is a common European mollusk, it is important to estimate potential of mussel as bioindicator for biomonitoring of freshwater ecosystems pollution. 


\section{Methods and Equipment}

The research was carried out using the facilities of the Equipment Sharing Centre KarRC RAS.

\subsection{Collecting and maintaining test organisms}

The mollusks $A$. cygnea were collected at the Ussuna River estuary $\left(62^{\circ} 20^{\prime} 29^{\prime \prime} \mathrm{N}\right.$, $33^{\circ} 48^{\prime} 54^{\prime \prime}$ E), northwestern Russia. This species is not under protection in this region. A group of uniform ( $C V=5.4 \%)$ animals, $71.8 \pm 2.8 \mathrm{~mm}$ in length, was selected for the experiment. The animals were placed into 4-litre aquariums with aerated tap water. Each aquarium contained 4 individuals. About $20^{\circ} \mathrm{C}$ water temperature was maintained by Hailea HC-250A thermostat. The water in the aquariums was completely replaced by the water with pre-prepared temperature and oxygenation every day (Table 1).

TABLE 1: Hydrochemical indicators of aquarium water.

\begin{tabular}{|c|}
\hline $\begin{array}{l}\mathrm{Cd}^{2+} \text { added } \\
\text { concentration, } \mu \mathrm{g} / \mathrm{L}\end{array}$ \\
\hline Exposuretime, hour \\
\hline $\mathrm{pH}$ \\
\hline Water temperature, ${ }^{\circ} \mathrm{C}$ \\
\hline $\begin{array}{l}\text { Oxygen } \\
\text { concentration, } \mathrm{mg} / \mathrm{L}\end{array}$ \\
\hline $\begin{array}{l}\mathrm{NO}^{2-} \text { concentration, } \\
\mathrm{mg} / \mathrm{L}\end{array}$ \\
\hline $\begin{array}{l}\mathrm{NO}^{3-} \text { concentration, } \\
\mathrm{mg} / \mathrm{L}\end{array}$ \\
\hline $\begin{array}{l}\mathrm{NH}^{4+} \text { concentration, } \\
\mathrm{mg} / \mathrm{L}\end{array}$ \\
\hline $\begin{array}{l}\mathrm{SO}_{4}{ }^{2-} \text { concentration, } \\
\mathrm{mg} / \mathrm{L}\end{array}$ \\
\hline $\begin{array}{l}\mathrm{Cl}^{-} \text {concentration, } \\
\mathrm{mg} / \mathrm{L}\end{array}$ \\
\hline $\begin{array}{l}\mathrm{PO}_{4}{ }^{3-} \text { concentration, } \\
\mathrm{mg} / \mathrm{L}\end{array}$ \\
\hline $\begin{array}{l}\mathrm{Na} \text { concentration, } \\
\mathrm{mg} / \mathrm{L}\end{array}$ \\
\hline $\begin{array}{l}\text { Mg concentration, } \\
\mathrm{mg} / \mathrm{L}\end{array}$ \\
\hline $\mathrm{K}$ concentration, $\mathrm{mg} / \mathrm{L}$ \\
\hline $\begin{array}{l}\text { Ca concentration, } \\
\mathrm{mg} / \mathrm{L}\end{array}$ \\
\hline $\begin{array}{l}\text { Cd concentration, } \\
\mathrm{mg} / \mathrm{L}\end{array}$ \\
\hline
\end{tabular}

\begin{tabular}{|c|c|}
\hline 0 & 10 \\
\hline 24 & 24 \\
\hline $6.9-7.0$ & $6.9-7.0$ \\
\hline $20 \pm 1$ & $20 \pm 1$ \\
\hline $7.0 \pm 0.1$ & $7.8 \pm 0.5$ \\
\hline$\leq 0.1$ & $\leq 0.1$ \\
\hline$\leq 5$ & $\leq 5$ \\
\hline 1.0 & 1.0 \\
\hline $14 \pm 1.4$ & $13.7 \pm 1.4$ \\
\hline $4.1 \pm 1.0$ & $4.5 \pm 1.1$ \\
\hline$\leq 0.25$ & $\leq 0.25$ \\
\hline 2.17 & 2.10 \\
\hline 1.88 & 1.77 \\
\hline 0.98 & 1.25 \\
\hline 7.16 & 5.95 \\
\hline $\begin{array}{c}0.08 \pm \\
0.01\end{array}$ & $\begin{array}{c}1.66 \pm \\
0.35\end{array}$ \\
\hline
\end{tabular}

\begin{tabular}{|c|}
\hline 50 \\
\hline 24 \\
7.0 \\
\hline $20 \pm 1$ \\
$7.1 \pm 0.1$ \\
\hline$\leq 0.1$ \\
\hline$\leq 5$ \\
\hline 2.0 \\
\hline $13.8 \pm 1.4$ \\
\hline $4.1 \pm 1.0$ \\
\hline$\leq 0.25$ \\
\hline 3.09 \\
\hline 1.78 \\
\hline 1.10 \\
\hline 6.00 \\
\hline 0.12 \\
\hline
\end{tabular}

\begin{tabular}{|c|c|}
\hline 100 & 0 \\
\hline 24 & 72 \\
\hline 7.0 & 7.2 \\
\hline $20 \pm 1$ & $20 \pm 1$ \\
\hline $7.7 \pm 0.4$ & $7.1 \pm 0.3$ \\
\hline$\leq 0.1$ & $\leq 0.1$ \\
\hline$\leq 5$ & $\leq 5$ \\
\hline 2.0 & 2.0 \\
\hline $14.1 \pm 1.4$ & $14 \pm 1.4$ \\
\hline $3.6 \pm 0.9$ & $4.1 \pm 1.0$ \\
\hline$\leq 0.25$ & $\leq 0.25$ \\
\hline 2.03 & 2.62 \\
\hline 1.36 & 1.17 \\
\hline 0.99 & 1.00 \\
\hline 5.92 & 5.91 \\
\hline $\begin{array}{c}58.45 \pm \\
2.69\end{array}$ & $\begin{array}{c}0.06 \pm \\
0.01\end{array}$ \\
\hline
\end{tabular}

\begin{tabular}{|c|c|c|}
\hline 10 & 50 & 100 \\
\hline 72 & 72 & 72 \\
\hline 6.9 & $6.9-7.0$ & 6.9 \\
\hline $20 \pm 1$ & $20 \pm 1$ & $20 \pm 1$ \\
\hline $7.2 \pm 0.3$ & $7.6 \pm 0.6$ & $7.4 \pm 0.3$ \\
\hline$\leq 0.1$ & $\leq 0.1$ & $\leq 0.1$ \\
\hline$\leq 5$ & $\leq 5$ & $\leq 5$ \\
\hline 2.0 & 2.0 & 2.0 \\
\hline $14.2 \pm 1.4$ & $14.7 \pm 1.5$ & $15.2 \pm 1.5$ \\
\hline $4.6 \pm 1.1$ & $4 \pm 1.0$ & $4.9 \pm 1.2$ \\
\hline$\leq 0.25$ & $\leq 0.25$ & $\leq 0.25$ \\
\hline 2.86 & 2.93 & 3.05 \\
\hline 1.87 & 1.91 & 1.89 \\
\hline 1.43 & 1.09 & 1.14 \\
\hline 7.25 & 6.70 & 7.23 \\
\hline $\begin{array}{c}1.85 \pm \\
0.15\end{array}$ & $\begin{array}{c}11.58 \pm \\
0.15\end{array}$ & $\begin{array}{c}15.06 \pm \\
2.38\end{array}$ \\
\hline
\end{tabular}


After the 12-day acclimation of the mollusks to laboratory conditions the aquariums were divided into a reference and an experimental group. Stock solution of $20 \mu \mathrm{g} / \mathrm{L}$ $\mathrm{CdCl} 2$ in distilled water was added to the experimental aquariums until the desired concentration (Table 2). Every day the aquaria were emptied and immediately filled with a new amount of prepared water to which a new portion of cadmium stock solution was added. Some of the animals were taken out for analysis one day after the beginning of the experiment (24-hour experiment) and others after the triple change of water with the addition of the metal (72-hour experiment). Cadmium salt was not added to the water in which the mollusks from the reference groups were kept. Each experiment was repeated twice. The mollusks were not fed during the entire acclimation period and the experiment.

TABLE 2: Experimental groups of $A$. cygnea.

\begin{tabular}{|l|c|c|c|c|c|c|c|c|}
\hline Group no. & 1 & 2 & 3 & 4 & 5 & 6 & 7 & 8 \\
\hline $\mathrm{Cd}^{2+}$ concentration added, $\mu \mathrm{g} / \mathrm{L}$ & 0 & 10 & 50 & 100 & 0 & 10 & 50 & 100 \\
\hline Duration of experiment, hours & 24 & 24 & 24 & 24 & 72 & 72 & 72 & 72 \\
\hline
\end{tabular}

\subsection{Hydrochemistry}

The $\mathrm{pH}$ level in the water was controlled every day using a Hanna $\mathrm{HI} 2210 \mathrm{pH}$-meter. Oxygen concentration was measured with a CCO-505 Elemetronoxymeter. Ammonium ion, nitrite and nitrate concentrations were measured using NILPA Niva Tropic aquarium express tests. The capillary electrophoresis system Kapel-104T, equipped with a quartz capillary was employed to measure sulphate, phosphate and chloride concentrations in the aquarium water of each group. Major cations ( $\mathrm{Na}, \mathrm{Ca}, \mathrm{K}, \mathrm{Mg}$ ) and cadmium concentrations in the aquarium water were measured by the mass-spectrometric method using an XSeries-2 ICP-MS (Thermo) [14]. Major water parameters are represented in the Appendix (Table 1).

\subsection{Measuring cadmium concentrations in the mollusk tissues}

Upon the end of the experimentone mollusk was taken from each aquarium, the soft tissues were separated from the shell, deep-frozen at $-80^{\circ} \mathrm{C}$ and subjected to FreeZone (Labconco) lyophilic drying. In addition, two individuals were taken immediately after catching from the river as control samples. The dried samples with a mass of $0.1 \mathrm{~g}$ were decomposed with a mixture of acids in an open system [15]. The samples were placed into teflon dish, adding up to $0.1 \mathrm{ml}$ of solution containing $8 \mu \mathrm{g} / \mathrm{L}$ of 161 Dy (checking 
chemical yield upon the decomposition of the samples) and wetted with several drops of deionized water. $0.5 \mathrm{ml}$ of $70 \% \mathrm{HClO}_{4}$ (Supratur, Merck), $3 \mathrm{ml}$ of $\mathrm{HF}$ and $0.5 \mathrm{ml}$ of $\mathrm{HNO} 3$ were then added and evaporated until intensive white vapor appeared. The acids $\mathrm{HF}, \mathrm{HNO} 3$ and $\mathrm{HCl}$ were re-purified in a PTFE/PFA SubboilingEcolR distillation device. The dishes were cooled, their walls were washed and the solution was evaporated again to moist salt. $2 \mathrm{ml}$ of $\mathrm{HCl}$ and $0.2 \mathrm{ml}$ of $0.1 \mathrm{MH}_{3} \mathrm{BO}_{3}$ solution were then added and evaporated until its volume was $0.5--0.7 \mathrm{ml}$. The solutions obtained were placed into polyethylene boxes and diluted with deionized water to a volume of $20 \mathrm{ml}$. The samples were then diluted 20 times and their cadmium concentrations were measured by the mass-spectrometric method on an XSeries-2 ICP-MS device.

\subsection{Biochemical analysis}

Upon the completion of the experiment the mollusks were taken from the aquariums, subjected to autopsy and their digestive gland and the gills were cut out. Immediately after the removal the tissues were frozen in liquid nitrogen and stored at $-80^{\circ} \mathrm{C}$ prior to analysis. The frozen 0.1-0.4 g samples were homogenized with a Digital Disruptor Genie homogenizer in $50 \mathrm{mMTris}-\mathrm{HCl}$ buffer $(\mathrm{pH} \mathrm{7.5)}$ at 5 -fold dilution. The homogenate was centrifuged at $60000 \mathrm{~g}$ for 1 hour at $4^{\circ} \mathrm{C}$ on a Beckman Coulter Allegra 64R centrifuge. The supernatant was used to estimate biochemical indices.

Superoxidedismutase(SOD) activity was measured spectrophotometrically according to Fridovich [16] with some modifications, based on the inhibition of autooxidation of adrenaline to adrenochrome by SOD in an alkaline environment. The homogenate was prepared using $0.3 \mathrm{M}$ bicarbonate buffer ( $\mathrm{pH}$ 10.6). To measure enzyme activity, 0.022 $\mathrm{M}$ adrenaline in $0.1 \mathrm{~N}$ hydrochloric acid was used. Measurements were carried out at a wave length of $480 \mathrm{~nm}$ for 1 minute at $25^{\circ} \mathrm{C}(\mathrm{U} / \mathrm{mg}$ protein * min-1).

Glutathione S-transferase(GST) activity was estimated from the rate of reduced glutathione (GSH) binding with the substrate 1-chloro-2.4-dinitrobenzene [17]. $0.225 \mu \mathrm{l}$ of reaction mixture, containing $1 \mathrm{mM} \mathrm{CDNB}$ and $1 \mathrm{mM} \mathrm{GSH}$ in $0.125 \mathrm{M}$ phosphate buffer (pH 6.5), were put into the plate cell. The reaction was started by the addition of 0.025 $\mu \mathrm{l}$ of homogenate solution. The increase of the optical density at a wavelength of 340 $\mathrm{nm}$ was recorded for $5 \mathrm{~min}$ at $25^{\circ} \mathrm{C}$ with a CLARIOstar Basic Unit reader (BMGLabtech, Germany).

Catalase (CAT) activity was measured according to Beers et al. [18] with some modifications. On the day of analysis, reaction mixture, containing $25 \mathrm{mM}$ hydrogen peroxide in $50 \mathrm{mMTris}-\mathrm{HCl}$ buffer $(\mathrm{pH} 7.5)$, was prepared. After the addition of the 
homogenate, hydrogen peroxide decomposition was measured for $3 \mathrm{~min}$ from the decrease of the solution optical density at a wavelength of $240 \mathrm{~nm}$ at $25^{\circ} \mathrm{C}$ ( $\mu \mathrm{M}$ hydrogen peroxide/mg protein * min).

Guaiacol-dependent peroxidase (Px) activity was measured using the modified method of Chance \&Maehly [19]. Reaction mixture contained $10 \mathrm{mMguaiacol}$ and $25 \mathrm{mM}$ peroxide in $50 \mathrm{mMTris}-\mathrm{HCl}$ buffer $(\mathrm{pH} \mathrm{7.5)}$, was prepared on the day of experiment. Measurements were done at a wavelength of $240 \mathrm{~nm}$ at $25^{\circ} \mathrm{C}$ after the addition of homogenate ( $\mu \mathrm{M}$ hydrogen peroxide/mg protein * min).

Reduced glutathione (GSH) concentrations were estimated using the modified methods of Hissin\&Hilf [20]. The dissolved homogenate proteins were precipitated by trichloroacetic acid (final concentration 5\%). After by centrifugation at $2500 \mathrm{~g}$ for $15 \mathrm{~min}$ the obtained supernatant was neutralized to $\mathrm{pH} 8.5$ with $5 \mathrm{~N} \mathrm{NaOH}$ and $0.4 \mathrm{M}$ tris- $\mathrm{HCl}$ buffer (pH 8.5), containing 5mM EDTA (Sigma-Aldrich). 0.01\% ortho-phthalicaldehyde in methanol, prepared immediately before its use, was then added to the reaction mixture. The solution was incubated at room temperature for $15 \mathrm{~min}$ and its fluorescence was measured ( $\mathrm{Em}-420 \mathrm{~nm}, \mathrm{Ex}-350 \mathrm{~nm}$ ) at $25^{\circ} \mathrm{C}$ ( $\mu \mathrm{g} \mathrm{GSH} / \mathrm{mg}$ protein).

Protein concentration in the supernatant was measured spectrophotometrically through the absorbance of a peptide bond at $220 \mathrm{~nm}$ at $26^{\circ} \mathrm{C}$ [20].

\subsection{Statistical analysis}

Samplings were compared by non-parametric one-way analysis (PERMANOVA). Posthoc test was carried out using Mann-Whitney non-parametric criterion. Correlations were analyzed with Spearman's rank correlation coefficient. The data were processed using an Excel and Past 3 software package. The data in the Figures and Tables are presented as a median \pm semi-interquartile range. The $p$-value $\leq 0.05$ was considered to be significant.

\section{Results}

\subsection{Hydrochemical indices and cadmium bioaccumulation}

Oxygen concentration, the temperature and $\mathrm{pH}$ of the water and the concentrations of biogenic compounds (ammonia, nitrites, nitrates, phosphates) and major anions (sulphates, phosphates and chlorides) and cations ( $\mathrm{Na}+, \mathrm{K}+, \mathrm{Ca} 2+, \mathrm{Mg} 2+$ ) during the experiment varied by no more than $10 \%$ (Appendix, Table 1). The amount of chloride 
ion added to the water with cadmium salt varied from 0.0038 to $0.038 \mathrm{~g} / \mathrm{L}(0.1-1 \%$ of background concentration) in different tanks, which is under the estimation limit of used method (Appendix, Table 1).

Regardless of the initial metal concentration, cadmium in water decreased considerably as early as 24 hours after placing the mollusks in to the tank (Table 2). After triple addition of 50 and $100 \mu \mathrm{g} / \mathrm{L}$ of $\mathrm{Cd} 2+$ per day the amount of cadmium in the water was smaller by 7 and $43 \%$, respectively, than after the 24 -hour experiment. Therefore, in the tissues of $A$. cygnea was conspicuous dose- and time-dependent cadmium accumulation (Table 2). It is shown that as the water cadmium increases from 10 to $100 \mu \mathrm{g} / \mathrm{L}$, the metal absorbed in tissues increases from 4 to $20 \mu \mathrm{g} \mathrm{Cd}^{2+}$ per gram of the dry weight. Noticeably, the rate of cadmium absorption by the mollusk tissue did not decline after triple exposure (Table 3).

TABLE 3: Cadmium concentration in the aquarium water and in the soft tissues of $A$. cygnea.

\begin{tabular}{l|c|c|c|}
$\begin{array}{l}\text { Initial concentration of } \\
\mathrm{Cd}^{2+} \text { in water, } \mu \mathrm{g} / \mathrm{L}\end{array}$ & $\begin{array}{c}\mathrm{Cd}^{2+} \text { added to each } \\
\text { aquarium }(\mathrm{V}=4 \mathrm{~L}), \mu \mathrm{g}\end{array}$ & $\begin{array}{c}\mathrm{Cd}^{2+} \text { concentration in } \\
\text { water after at the end } \\
\text { of experiment, } \mu \mathrm{g} / \mathrm{L}\end{array}$ & $\begin{array}{c}\mathrm{Cd}^{2+} \text { concentration in soft } \\
\text { tissues of } A \text {. cygnea }(\mathrm{n}=2), \\
\mu \mathrm{g} / \mathrm{g} \text { dry mass }\end{array}$ \\
\hline after 24 hours & 0 & $0.08 \pm 0.01$ & $0.85 \pm 0.01$ \\
\hline 0.006 (control) & 40 & $1.66 \pm 0.35$ & $3.90 \pm 0.38$ \\
\hline 10 & 200 & $18.53 \pm 0.12$ & $13.03 \pm 0.19$ \\
\hline 50 & 400 & $58.45 \pm 2.69$ & $20.34 \pm 0.09$ \\
\hline 100 & 0 & & $0.06 \pm 0.01$ \\
\hline after 72 hours (triple addition of $\mathrm{Cd}{ }^{2+}$ ones a day) & $1.85 \pm 0.15$ & $8.45 \pm 0.28$ \\
\hline 0.006 (control) & 120 & $11.58 \pm 0.15$ & $40.90 \pm 4.99$ \\
\hline 10 & 600 & $15.06 \pm 2.38$ & $57.61 \pm 3.99$ \\
\hline 50 & 1200 & & \\
\hline 100 & & & 0.01 \\
\hline
\end{tabular}

\subsection{Response to cadmium in the gills of the mollusks}

24 hours after the addition of 50 and $100 \mu \mathrm{g} / \mathrm{L}$ of cadmium the concentration of reduced glutathione $(\mathrm{GSH})$ in the mollusk gills decreased two-fold, while a cadmium concentration of $10 \mu \mathrm{g} / \mathrm{L}$ did not affect the GSH level in this organ (Figure 1 (1) A). The double decline of reduced glutathione concentration was also observed in gills of mollusks from reference aquariums after the triple daily water replacement in comparison with the mollusks which were kept for 24 hours in cadmium-free aquariums. After triple daily exposure of 10 and $50 \mu \mathrm{g} / \mathrm{L}$ of cadmium in the water, GSH concentration in the gills tended to rise (statistically insignificantly) in comparison with the mollusks from the reference group, and upon the addition of the metal at a concentration of $100 \mu \mathrm{g} / \mathrm{L}$ 
the increase was four-fold, exceeding the GSH variability in mollusks from all the rest aquariums. Glutathione S-transferase (GST) activity in the gills of the mollusks (Figure 1 (1) C) increased 1.8-2.1 times in all the aquariums during one day after the single addition of cadmium. After three serial exposures for 24 hours elevation of GST activity was observed in the gills only at cadmium ion concentration of $10 \mu \mathrm{g} / \mathrm{L}$, while at 50 and $100 \mu \mathrm{g} / \mathrm{L}$ GST activity in the gills did not differ statistically significant from that of the mollusks from aquariums with no cadmium salts.

\subsubsection{Gills}
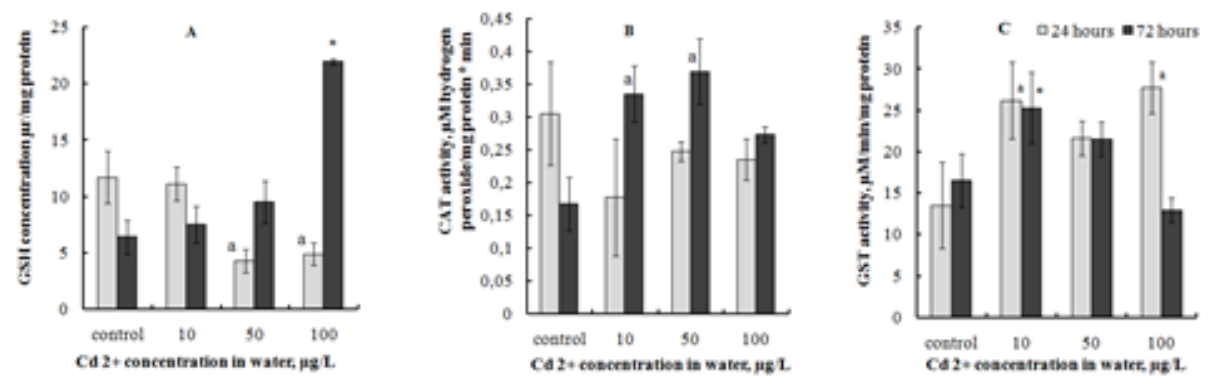

\subsection{2. digestive gland}
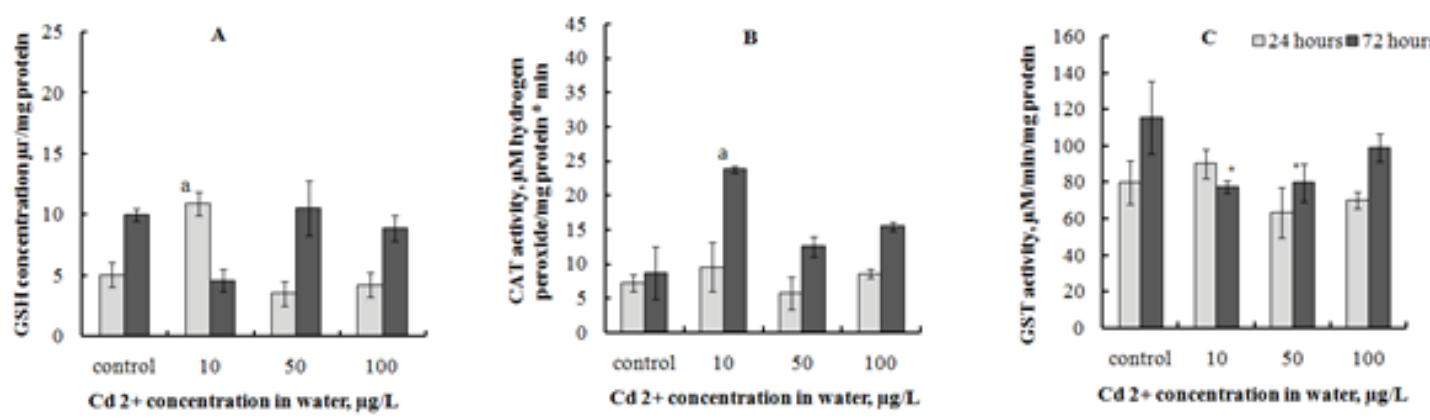

Figure 1: GSH concentration (A), catalase (B) and glutathione-S-transferase (C) activity in the gills (1) and digestive gland (2) of the bivalve mollusks $A$. cygnea upon the single and triple daily addition of various cadmium concentrations.

a -- statistically significant differences compared to the mollusks kept for 24 hours in the cadmium-free aquaria.

* - statistically significant differences compared to the mollusks kept for 72 hours in cadmium-free aquaria.

During 24 hours after the addition of cadmium chloride the activity of the enzyme superoxide dismuthase (SOD) in the gills of the mollusk was roughly doubled (Table 4), however there were no statistically significant differences in activity among animals subjected to various cadmium concentrations. The similar double increase in SOD activity was shown for the reference group in the 72-hour experiment and in the aquariums to which $100 \mu \mathrm{g} / \mathrm{L}$ of cadmium was added. Thus, the effect of the water 
replacements on SOD activity in the gills was as strong as the addition of the polluting agent.

TABLE 4: Superoxide dismutase activity in the gills of the bivalve mollusks $A$. cygnea upon the single and triple daily addition of various cadmium concentrations.

\begin{tabular}{l|c|c|c|c|}
\hline $\begin{array}{l}\mathrm{Cd}^{2+} \text { concentration } \\
\text { Experiment }\end{array}$ & control, $0 \mu \mathrm{g} / \mathrm{L}$ & $10 \mu \mathrm{g} / \mathrm{L}$ & $50 \mu \mathrm{g} / \mathrm{L}$ & $100 \mu \mathrm{g} / \mathrm{L}$ \\
\hline 24 hours & $0.018 \pm 0.004$ & $0.037 \pm 0.005^{a}$ & $0.046 \pm 0.007^{a}$ & $0.039 \pm 0.008^{a}$ \\
\hline 72 hours & $0.030 \pm 0.005$ & - & - & $0.034 \pm 0.007$ \\
\hline
\end{tabular}

a-- statisticallyvaliddifferences $(p \leq 0.05)$ relative to the mollusks kept in cadmium-free aquariums.

Peroxidase activity $(\mathrm{Px})$ in the gills of the mollusks 24 hours after the addition of cadmium was the higher; the higher was the concentration of cadmium in the water. At cadmium concentration of $100 \mu \mathrm{g} / \mathrm{L}$ it was three times higher that of the reference samples (Table 5).

TABLE 5: Peroxidase activity $\left(\mu \mathrm{M} \mathrm{H}_{2} \mathrm{O}_{2} / \mathrm{mg}\right.$ protein * min) in the gills of the bivalve mollusks $A$. cygnea upon the single and triple daily addition of various cadmium concentrations.

\begin{tabular}{l|c|c|c|c|}
\hline $\begin{array}{l}\mathrm{Cd}^{2+} \text { concentration } \\
\text { Experiment }\end{array}$ & control, $0 \mu \mathrm{g} / \mathrm{L}$ & $10 \mu \mathrm{g} / \mathrm{L}$ & $50 \mu \mathrm{g} / \mathrm{L}$ & $100 \mu \mathrm{g} / \mathrm{L}$ \\
\hline 24 hours & $0.161 \pm 0.061$ & $0.881 \pm 0.268^{a}$ & $0.302 \pm 0.050^{a}$ & $1.415 \pm 0.227^{a}$ \\
\hline 72 hours & $1.501 \pm 0.157^{*}$ & - & $0.095 \pm 0.033^{a, *}$ & $0.088 \pm 0.007^{a, *}$ \\
\hline
\end{tabular}

a -- statistically significant differences $(\mathrm{p} \leq 0.05)$ relative tothe mollusks kept in cadmium-free aquaria.

* -- statistically significant differences $(p \leq 0.05)$ relative to the mollusks in the experiment with the single addition of cadmium followed by 24 -hour exposure.

However, a similar rise in activity was observed for the reference group in the 72-hour experiment, where it could have been provoked by stress from the two-fold replacement of water. After triple daily addition of 50 and $100 \mu \mathrm{g} / \mathrm{L}$ of cadmium Pxthe activity in the gills declined markedly in comparison with the mollusks from the cadmium-free aquariums and the values obtained for the gills 24 hours after the single addition of the same cadmium concentrations.

Response to cadmium in the digestive gland of the mollusks.GSH concentration in the digestive gland halved after a single placement of mollusks into $10 \mu \mathrm{g} / \mathrm{L}$ water cadmium in comparison with the animals from the reference group (Figure 1 (2) A) and was unaffected by higher cadmium concentrations (50 and $100 \mu \mathrm{g} / \mathrm{L}$ ). After the three times water replacement with and without cadmium GSH concentration in the digestive gland of the mollusks from all the aquariums was also twice as high as that of the mollusks kept for one day, except for the aquarium to which $10 \mu \mathrm{g} / \mathrm{L} \mathrm{Cd} 2+$ was added. No changes in CAT activity in the digestive gland upon 24-hour exposure to cadmium were observed in contrast to the mollusks from cadmium-free aquariums (Figure 1 (2) B). The serial replacement of water (72-hour exposure) resulted in a two-fold rise in CAT 
activity only at a $\mathrm{Cd}^{2+}$ concentration of $10 \mu \mathrm{g} / \mathrm{L}$. Similarly, GST activity in the digestive gland of $A$. cygnea remained unchanged 24 hours after the addition of various cadmium concentrations (Figure 1 (2) C). However, GST activity was observed to decrease in the digestive gland of the mollusks placed three times into 10 and $50 \mu \mathrm{g} / \mathrm{L}$ of $\mathrm{Cd}^{2+}$ for a day in comparison with the mollusks from cadmium-free aquariums. No statistically valid correlations between superoxide dismutase (SOD), peroxidase (Px), catalase (CAT) and glutathione S-transferase (GST) activities and reduced glutathione (GSH) concentration in the gills and digestive gland of the mollusks were found.

\section{Discussion}

A. cygnea is known to be a freshwater bottom filtrator. While passing water through itself, the mollusk adsorbs dissolved metal ions through the mantle and other soft tissues and also by its shell [22]. Excessive accumulation of cadmium can lead to impaired functioning of the animal's enzyme systems, rapid oxidation progression and the animal death. For the ecosystem the long-term negative effect of $\mathrm{Cd}$ pollution is due to the ability of the metal to permanently circulate in the food chain, in which the filtrators is often a nodal element [23].

Our study has confirmed the ability of $A$. cygnea to actively accumulate cadmium in the soft tissues (Figure 2). The higher the cadmium concentration in water (i.e. the greater the amount of its ions passing through the filtration system of $A$. cygnea per unit time), the higher the absorption rate of the element. Calculations show that with the average mass of the lyophilized soft tissues of one mollusk of $2.16 \pm 0.10 \mathrm{~g}$ it could accumulate up to $44 \mu \mathrm{g}$ of the metal per day in aquariums with a maximum tested cadmium concentration of $100 \mu \mathrm{g} / \mathrm{L}$. Upon the tree time replication of the exposure the metal accumulation increased linearly, reaching the estimated value $124 \mu \mathrm{g}$ of cadmium per mollusk by the end of the third day. There were no sign of slowing down the accumulation over time or with increasing concentration of the polluting agent. At the same time no visible pathological changes or animal deaths took place in all tested groups of mollusks, indicating that above amount of the pollutant in the tissues of $A$. cygnea is not ultimate. In spite of active metal absorption, the mollusk can presume ably tolerate the short-term effect of $\mathrm{Cd}$ concentrations higher than those tested. This agrees with the results of the studies showing that a $50 \%$ lethal dose of cadmium for the sea mollusk Modiolusphilippinarumwas $300 \mu \mathrm{g} / \mathrm{L}$ for 72 hours and for Donaxtrunculus $2600 \mu \mathrm{g} / \mathrm{L}$ of $\mathrm{Cd}^{2+}$ for 96 hours, which is higher by one order of magnitude than the concentrations we tested [24]. 


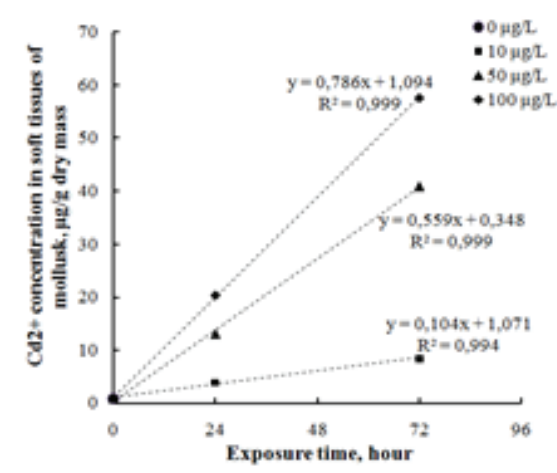

Figure 2: $\mathrm{Cd}^{2+}$ accumulation dynamics in the soft tissues of the mollusk. The point «0 hours» is consistent with $\mathrm{Cd}$ concentration in the wild mollusk taken from the river.

As Acygnea has been shown to be able to accumulate high heavy metal concentrations and could stay alive, it is a good candidate to be bioindicator of industrial pollution and could be effectively used for cleaning of heavy metal-polluted water. The obtained data also support the need to assess the environmental condition of water bodies for the commercial breeding of bivalve mollusks as food. It has been shown previously, that the presence of mollusks in diet correlated with human diseases provoked by $\mathrm{Cd}$ accumulation [25].

Cadmium poisoning is known to be associated with the oxidative stress development. This metal has a high affinity for $\mathrm{SH}$-groups and bind low-molecular anti-oxidant thiolbearing peptides such as reduced glutathione and metallothionein. The increased synthesis of these molecules upon the chronic effect of cadmium is a protective mechanism which blocks the toxic agent [26]. The depletion of anti-oxidant peptide pool due to their combining with cadmium is in turn, the most essential mechanism of the development of metal-provoked oxidative stress. Our studies have shown that the cadmium accumulation leads to changes in GSH concentration in the mollusk tissues as early as 24 hours after the addition of cadmium (Figure 1 (1) C, (2) B). The GSH level was twice as low in the gills of the animals in the aquaria to which 50 and 100 $\mu \mathrm{g} / \mathrm{ml}$ of cadmium were once added, most probably due to the formation of stable complexes (GS-Cd). Upon the three-time addition of $50 \mu \mathrm{g} / \mathrm{L}$ of cadmium per day the glutathione level in the gills is restored to the initial value and increases rapidly twofold upon the addition of $100 \mu \mathrm{g} / \mathrm{L}$ of cadmium (Figure 1 (1) C). This seems to indicate that upon the prolonged exposure of the toxicant, after the depletion of the available glutathione reserves on a third dayreduced glutathione is actively synthesized in the gills de novo. This response could be the mechanism of mollusk adaptation to pollution with large doses of cadmium, which allows GSH blocking exogenous substances and remove oxidation products [27]. The digestive gland of $A$. cygnea, in turn, displays a 
two-fold increase in the glutathione level upon the single addition of $10 \mu \mathrm{g} / \mathrm{L}$ cadmium in comparison with the animals from the reference aquariums. However, upon the three-fold addition of the same cadmium concentration the glutathione reserves were depleted (Figure 1 (2) C). The effect of higher cadmium concentrations of 50 and 100 $\mu \mathrm{g} / \mathrm{L}$ for three days resulted in the recovery of the peptide level in digestive gland presumably through the synthesis of new molecules. Thus, the tested concentrations do not exceed the ability of the mollusk organism to maintain the required concentration of protective low-molecular thiol-bearing peptides which provide the buffer capacity of internal media.

A variation in glutathione concentration in the tissues of the mollusks from reference cadmium-free aquariums 24 and 72 hours after the beginning of the experiment is noteworthy. Consequently, the daily changing of water, even for a short time is stessfuul and could lead to considerable changes in the GSH level in the gills and the digestive gland of $A$. cygnea.

Superoxide dismutase is known to be an essential component of the enzymatic AOS of aquatic organisms [28] and is the first line of protection from ROS.The enzyme catalysis the dismutation of superoxide anions (O2 -) into less toxic hydrogen peroxide $\left(\mathrm{H}_{2} \mathrm{O}_{2}\right)$, which is then converted into water and molecular oxygen by other AOS enzymes. In our experiment, SOD activity in the gills of the mollusks from all experimental groups increased 24 hours after the beginning of the exposure, but the activity of this enzyme was not found to correlate with cadmium concentration (Table 3). The increase of the activity or expression of SOD was shown earlier for the mollusk Ruditapesdecussatusexposed to a 4--100 $\mathrm{\mu g} / \mathrm{LCd}^{2+}$ [29] and for the freshwater crab Sinopotamonyangtsekienseafter exposure to 7.2 and $14.5 \mu \mathrm{g} / \mathrm{L}$ of $\mathrm{Cd}^{2+}$ [30]. Hamilton et al. [31], in turn, report the absence of well-defined relationship between Cd concentration and the SOD in the embryos of the horseshoe-shaped crab (Limulus polyphemus). It has been show previously that superoxide dismutase activity can be easily inhibited by cadmium, which replaces other metal ions in the active centre of the enzyme [6]. The increase of SOD activity in our experiment through the stimulation of protein expression, could be a compensatory response to the inhibition of the enzyme by cadmium ions.

Oxidative stress products, such as peroxides, can be utilized using the enzyme peroxidase [11]. Studies of bivalve sea mollusks indicate the increased activity of SOD, which produces hydrogen peroxide and $\mathrm{Px}$, which splits it up, being influenced by cadmium ions [32]. The genes of these enzymes were observed to be induced in fish affected by $\mathrm{Cd}^{2+}$ at a concentration of $0.3 \mu \mathrm{g} / \mathrm{L}$ in the brown trout Salmotrutta[33], and at a concentration of $0.7 \mu \mathrm{g} / \mathrm{L}$ in the sea bass Dicentrarchus/abrax[34]. In our study, the 
exposure of cadmium ions for 24 hours also results in increased Px activity in comparison with the reference group. However, on a third day the experiment activity was shown to increase 15-17 times, and was lower than in the reference group and groups subjected to the same concentrations for 24-hour (Table 4). Under the prolonged exposure of cadmium, activity could have been decreased by inhibition of enzyme expression, e.g. individual Px isoforms was shown to have differing insusceptibility to the toxic effect of cadmium [35]. It should be noted that manipulations with water in aquariums seem to provoke oxidative stress in Anadonta, comparable in level to the single addition of 100 $\mu \mathrm{g} / \mathrm{L}$ of cadmium ions as indicated by the increase of Px activity in the mollusks from the reference aquarium in 24-hour and 72-hour experiment.

Like peroxidase, catalase splits up hydrogen peroxide into harmless water and oxygen molecules [36]. Our study has shown that in the tissues of $A$. cygnea cadmium affects CAT activity only after triple addition every day, indicating that CAT is slightly sensitive to such an effect (Figure 1 (1) A, (2) A). CAT decreased in the gills of $A$. cygnea in the reference group 72 hours after the beginning of the experiment, indicating the high sensitivity of the enzyme to a variety of stress factors, e.g. daily changing water. The digestive gland of the mollusks after three repeated additions of cadmium salts displayed a 2.5 -fold rise in catalase activity at $10 \mu \mathrm{g} / \mathrm{L}$ of cadmium and a slight increase at 50 and $100 \mu \mathrm{g} / \mathrm{L}$. This increase can be interpreted as the adaptive response of CAT to heavy metal ions similar to what has been shown for Crassostreagigasfrom areas heavily polluted by cadmium [11]. The increase of catalase activity in the digestive glands coincided with the decrease of the reduced glutathione level in these tissues possibly used for binding cadmium. Inhibition of CAT by cadmium ions was shown in vitro [6], therefore, the absence of the well-defined effect of cadmium on enzyme activity (except for a cadmium concentration of $10 \mu \mathrm{g} / \mathrm{L}$ ) in our experiment can indicate the poor accessibility of this element to CAT, e.g. through its absorption by low-molecular thiolbearing peptides.

The cells are also protected against oxidative damage by the enzymes of glutathione S-transferase fulfilling the functions of peroxidases and isomerases [37]. The increase of GST activity in the gills after 24 hours at a concentration of $10 \mu \mathrm{g} / \mathrm{L}$ of $\mathrm{Cd}^{2+}$ suggests its involvement in compensatory reactions protecting against cadmium (Figure 1 (1) B). For instance, the acute cadmium poisoning of the sea mollusk Donaxtrunculusby high $2590 \mu \mathrm{g} / \mathrm{L}$ concentrations of $\mathrm{Cd} 2+$ resulted in the consecutive increase in GST activity during 0, 24, 48, 72 and 96 hours [23]. However, after 72-hour exposure to $100 \mu \mathrm{g} / \mathrm{L}$ of cadmium in our experiment GST activity in the gills of $A$. cygnea decreased. In Pinheiroet al., [38] studies, GST activity in the mussel Mytilusgalloprovincialis, affected 
by various toxic agents, displayed the same two-phase (increase followed by decrease) response. We assume that the longer influence of cadmium ions at concentrations of 10 and $50 \mu \mathrm{g} / \mathrm{ml}$ can later result in the lowered activity of this enzyme in the gills. The decrease of GST activity in the digestive gland was observed 72 hours after the three-fold addition of 10 and $50 \mu \mathrm{g} / \mathrm{ml}$ of cadmium (Figure 1 (2) B). In this case, there was no increase and subsequent decrease of GST activity in the gills. There are no data in the literature showing that cadmium can be irreversibly bind with glutathione S-transferase, but it has been shown that cadmium can inhibit the synthesis of this enzyme [39]. According to this, decrease of GST activity could have been caused by changes in gene expression under heavy metal exposure, which takes for some time to rearrange protein biosynthesis. It could be concluded, that the activity of AOS enzymes of $A$. cygnea depends on metal concentration, time of exposure and the metabolic activity of a particular organ.

\section{Conclusion}

The obtained results provide a better understanding of biochemical adaptation mechanisms which contribute to the survival of aquatic organisms in a stress environment. Cd accumulation rate in the organism of the freshwater mollusk A.cygnea was shown to increase with increasing $\mathrm{Cd}$ concentration. Signs of oxidative stress, such as elevated SOD activity and the increase of CAT, Px and GST activity followed by their decrease, were revealed. The ability of the mollusk to restore the reserves of low-molecular thiolbearing peptides, including reduced glutathione, which can block cadmium ions, could be an essential mechanism which contributes to the survival of the mollusks at high $\mathrm{Cd} 2+$ concentrations (10-100 $\mu \mathrm{g} / \mathrm{L})$. Consequently, A.cygnea can be chosen as model organisms for pollution adaptation studies.

\section{Funding}

The study was supported by RFBR grant 17-04-01431_a and under state order (project № 0218-2018-0076)

\section{Conflict of Interest}

The authors have no conflict of interest to declare. 


\section{References}

[1] Benavides, M.P., Gallego, S.M., Tomaro, M.L. (2005). Cadmium toxicity in plants Braz. J. Plant Physiol., vol. 17, No 1, pp. 21--34. doi: 10.1590/S1677-04202005000100003.

[2] Bigot, A., Minguez, L., Giamberini, L., Rodius, F. (2011). Early defense responses in the freshwater bivalve Corbiculafluminea exposed to copper and cadmium: transcriptional and his to chemical studies. Environ. Toxicol., vol. 26, pp. 623-632. doi: $10.1002 /$ tox.20599.

[3] Choi, C.Y., An, K.W., Nelson, E.R., Habibi, H.R. (2007). Cadmium affects the expression of metallothionein (MT) and glutathione peroxidase (GPX) mRNA in goldfish, Carassiusauratus. Comp. Biochem. Physiol. C., vol. 145, No 4. pp. 595 - 600. doi: 10.1179/oeh.2007.13.2.202.

[4] Glenn, V.D. (2002). Hazardous substances from the CERCLA Priority List of Hazardous Substances for 2001 Electron. Resour. Rev., vol. 16, No 6, pp. 29-30. doi:10.1108/rr.2002.16.6.29.301.

[5] Klaassen, C.D., Liu, J., Diwan, B.A. (2009). Review Metallothionein protection of cadmium toxicity.Toxicol. Appl. Pharmacol., vol. 238, No 3, pp. 215-220. doi: 10.1016/j.taap.2009.03.026.

[6] Casalino, E., Calzaretti, G., Sblano, C., Landriscina, V., Felice, Tecce, M., Landriscina, C. (2002). Antioxidant effect of hydroxytyrosol (DPE) and $\mathrm{Mn}^{2+}$ in liver of cadmiumintoxicated rats. Comp. Biochem. Physiol. C. Toxicol. Pharmacol., vol. 133(4). pp. 625-632.

[7] Flora, G., Gupta, D., Tiwari, A. (2012). Toxicity of lead: a review with recent updates. Interdiscip. Toxicol., vol. 5, No 2. pp. 47--58. doi: 10.2478/v10102-012-0009-2.

[8] Regoli, F., Giuliani, M.E.(2013).Oxidativepathways of chemical toxicity and oxidative stress biomarkers in marine organisms. Mar. Environ. Res. 2014, vol. 93, pp. 106--117. doi: 10.1016/j.marenvres. 2013.07.006

[9] Vega-López, A., Ayala-López, G., Posadas-Espadas, B.P., Olivares-Rubio, H.F., DzulCaamal, R. (2013). Relations of oxidative stress in freshwater phytoplankton with heavy metals and polycyclic aromatic hydrocarbons. Comp. Biochem. Physiol. A Mol. Integr. Physiol., vol. 165, No. 4, pp. 498--507. doi: 10.1016/j.cbpa.2013.01.026.

[10] Kim, M.O., Phyllis, E.B. (1998). Oxidative stress in critical care: is antioxidant supplementation beneficial. J. Am. Diet. Assoc., vol. 98. pp. 1001--1008.

[11] Jo, J.G., Choi, Y.K., Choi, C.Y. (2008). Cloning and mRNA expression of antioxidant enzymes in the Pacific oyster, Crassostreagigasin response to cadmium exposure. Comp. Biochem. Physiol. C., vol. 147, No 4, pp. 460--469. 
[12] Poteat, M.D., Garland, T.J., Fisher N.S., Wang W.X., Buchwalter D.B. (2013). Evolutionary patterns in trace metal (cd and zn) efflux capacity in aquatic organisms. Environ. Sci. Technol., vol. 47, No 14, pp. 7989-7995.

[13] Pan, K., Wang, W.X. (2012). Trace metal contamination in estuarine and coastal environments in China. Sci. Total Environ., vol. 421-422, pp. 3-16. doi: 10.1016/j.scitotenv.2011.03.013.

[14] Slukovskii, Z.I., Polyakova, T.N. (2017). Analysis of Accumulation of Heavy Metals from River Bottom Sediments of the Urban Environment in the Bodies of Oligochaetes. Inland Water Biology., vol. 10, No 3. pp. 315-322.

[15] Slukovskiy, Z.I. (2015) Normalization of the Concentrations of Heavy Metals with Respect to Lithium in Bottom Sediments of Lakes Ladozhskoye and Chetyrekhverstnoye (Republic of Karelia). Chemistry for Sustainable Development, No 4, pp. 397-408 (in Russian).

[16] Fridovich, I. (1975). Superoxide dismutases. Annu. Rev. Biochem., vol. 44, pp. 147--159.

[17] Habig, W.H., Pabst, M.J., Jakoby, W. B. (1974). Glutathione S-Transferases. The first enzymatic step in mercapturic acid formation. J. Biol. Chem., vol. 249, No 22, P. 7130-7139.

[18] Beers, R.F.Jr., Sizer, I.W. (1952). A spectrophotometric method for measuring the breakdown of hydrogen peroxide by catalase. Biol. Chem., vol. 195, No 1, pp. 133140.

[19] Chance B., Maehly, A.C. (1955). Assay of catalase and peroxidases. Methods Enzymol, vol. 2, pp. 764-775.

[20] Hissin, P.J., Hilf, R. (1976). A fluorometric method for determination of oxidized and reduced glutathione in tissues. Anal. Biochem. vol. 74, No 1, pp. 214--226.

[21] Noble, J.E., Bailey, M.A. (2009). Quantitation of Protein. Methods in Enzymology, vol. 463, pp. 73-95. doi: 10.1016/S0076-6879(09)63008-1.

[22] Nan, G., Peifang, W., Chao, W., Jun, H., Jin, Q., Lingzhan, M. (2016). Mechanisms of cadmium accumulation (adsorption and absorption) by the freshwater bivalve Corbiculafluminea under hydrodynamic conditions. Environ. Pollut., vol. 212, pp. 550558. doi: 10.1016/j.envpol.2016.01.091.

[23] Eisler, R. (1985). Cadmium hazards to fish, wildlife, invertebrates: A synoptic review. U.S. Fish and Wildlife Service Biological Report, No 85 (1.2), Washington D.C. pp. 1 46.

[24] Ramakritinan, C.M., Chandurvelan, R., Kumaguru, A.K. (2012). Acute toxicity of metals: $\mathrm{Cu}, \mathrm{Pb}, \mathrm{Cd}, \mathrm{Hg}$ and $\mathrm{Zn}$ on marine mollusks, Cerithediacingulata $\mathrm{G}$., and 
Modiolusphilippinarum H. Indian Journal of Geo-Marine Sciences., vol. 41(2), pp. 141-145.

[25] Whyte, A.L., Hook, G.R., Greening, G.E., Gibbs-Smith, E., Gardner, J.P. (2009). Human dietary exposure to heavy metals via the consumption of greenshell mussels (PernacanaliculusGmelin 1791) from the Bay of Islands, northern New Zealand. Sci. Total Environ., vol. 407, No. 14, pp. 4348--4355. doi: 10.1016/j.scitotenv.2009.04.011.

[26] Brzóska, M.M., Moniuszko-Jakoniuk, J., Jurczuk, M., Gałazyn-Sidorczuk, M., Rogalska, J. (2000). Effect of short-term ethanol administration on cadmium retention and bioelement metabolism in rats continuously exposed to cadmium. Alcohol Alcohol., vol. 35(5), pp. 439-45. doi: 10.1093/alcalc/35.5.439.

[27] Meng, J., Wang, W., Li, L., Yin, Q., Zhang, G. (2017). Cadmium effects on DNA and protein metabolism in oyster (Crassostreagigas) revealed by proteomic analyses. Sci. Rep., vol. 7, No 1, P. 11716. doi: 10.1038/s41598-017-11894-7.

[28] Fanjul-Moles, M.L., Gonsebatt, M.E. (2011). Oxidative stress and antioxidant systems in crustacean life cycles. In: Abele, D., Zentano-Savin, T., Vazquez-Medina, J. (eds) Oxidative stress in aquatic ecosystems. Wiley-Blackwell, Hoboken. P. 208--223.

[29] Geret, F., Serafim, A., Barreira, L., Bebianno, M.J. (2002). Effects of cadmium on antioxidant enzyme activities and lipid peroxidation in the gills of the clam, Ruditapes decussates. Biomarkers. vol. 7, No 3, pp. 242--256.

[30] Lei, W., Wang, L., Liu, D., Xu, T., Luo, J. (2011). Histopathological and biochemical alternations of the heart induced by acute cadmium exposure in the freshwater crab Sinopotamonyangtsekiense. Chemosphere, vol. 84, No 5, pp. 689--694. doi: 10.1016/j.chemosphere.2011.03.023.

[31] Hamilton M.G., Esposito C., Malin M., Cusumano L.R., Botton M.L. (2015). Effects of copper and cadmium on development and superoxide dismutase levels in horseshoe crab (Limulus polyphemus) embryos. Springerplus, vol. 4, P. 504. doi: 10.1186/s40064-015-1267-1.

[32] Funes, V., Alhama, J., Navas, J.I., Lopéz-Barea, J., Peinado, J. (2006). Ecotoxicological effects of metal pollution in two mollusc species from the Spanish South Atlantic littoral. Environ. Pollut., vol. 139, No 2, pp. 214--223. doi: 10.1016/j.envpol.2005.05.016.

[33] Hansen, B.H., Garmo, O.A., Olsvik, P.A., Andersen, R.A. (2007). Gill metal binding and stress gene transcription in brown trout (Salmotrutta) exposed to metal environments: the effect of pre-exposure in natural populations. Environ. Toxicol. Chem., vol. 26, No 5. pp. 944-953.

[34] Roméo, M., Bennani, N., Gnassia-Barelli, M., Lafaurie, M., Girard, J.P. (2000). Cadmium and copper display different responses towards oxidative stress in the kidney of the 
sea bass Dicentrarchuslabrax. AquatToxicol., vol. 1, No 48(2-3), pp. 185-194.

[35] Tamás, L., Durceková K., Halusková L., Huttová J., Mistrík I., Ollé M. (2007). Rhizosphere localized cationic peroxidase from barley roots is strongly activated by cadmium and correlated with root growth inhibition. Chemosphere, vol. 66(7), pp. 1292-300.

[36] Kashiwagi, A., Kashiwagi, K., Takase, M., Hanada, H., Nakamura, M. (1997). Comparison of catalase in diploid and haploid Ranarugosa using heat and chemical inactivation techniques. Comp. Biochem. Physiol. B Biochem. Mol. Biol., vol. 118, No 3, pp. 499-503.

[37] Frova, C. (2006). Glutathione Transferases in the Genomics Era: New Insights and Perspectives. Biomol. Eng., vol. 23, No 4, pp. 149--169. doi: 10.1016/j.bioeng.2006.05.020.

[38] Pinheiro, M., Caetano, M., Neuparth, T., Barros, S., Soares, J., Raimundo, J., Vale, C., Coimbra, J., Castro, L.F.C., Santos, M.M. (2019). Ecotoxicology of deep-sea environments: Functional and biochemical effects of suspended sediments in the model species Mytilusgalloprovincialis under hyperbaric conditions. Sci. Total Environ., vol. 670, pp. 218-225. doi: 10.1016/j.scitotenv.2019.03.196.

[39] Sidhu, M., Prasad, R., Gill, K.D., Nath, R. (1997). Alterations in isoforms of glutathione S-transferase in liver and kidney of cadmium exposed rhesus monkeys: purification and kinetic characterization. Mol Cell Biochem., vol. 166 (1-2), pp. 55-63. DOI: 10.1023/a:1006849431209. 